\title{
Ostatnie słowo w sprawie twórczości Michała Kozłowskiego
}

Z pewnym zaskoczeniem przyjąłem publikację na łamach „Przeglądu Historyczno-Wojskowego" odpowiedzi ${ }^{1}$ na mój artykuł recenzyjny ${ }^{2}$ poświęcony publikacji Michała Kozłowskiego ${ }^{3}$.

Celem mojego artykułu nie była polemika z tezami zawartymi w treści tekstu Kozłowskiego. Intencją moją było wskazanie rażących błędów, ewidentnych zaniedbań, jawnych niekompetencji tuszowanych nierzadko cwaniactwem. Kozłowski zechciał się do moich zarzutów odnieść, odpowiadając na nie ni to atakiem, ni to obroną, jak też nie ustosunkowując się do meritum, moich uwag. W jego wywodzie pojawia się kilka wątków, w których imputuje mi „nieprawdę”, „nietrafione uwagi”, „wrażenia literackie”. Zmusza mnie tym samym do odpowiedzi, tyleż dla mnie kłopotliwej, że sprowadzić ją muszę do wywołanych przez Kozłowskiego kwestii.

\section{I}

„Autor polemiki zarzucił mi nieprzeprowadzenie kwerendy w Archiwum Uniwersytetu Warszawskiego (UW). Faktycznie, ze względu na objętość i czas powstania tekstu nie było to możliwe. Przeprowadzanie z kolei badań w Archiwum Politechniki Warszawskiej oczywiście byłoby potrzebne, gdybym pisał książkę o wszystkich uczniach Stanisława Herbsta. Jednak celowo ograniczyłem artykuł do wskazania jedynie tych uczniów warszawskiego historyka, którzy zajmowali się historią wojskowości”" .

${ }^{1}$ M. Kozłowski, W odpowiedzi Tomaszowi Siewierskiemu, „Przegląd Historyczno-Wojskowy" (PHW) 2020, nr 2 (272), s. 217-219.

${ }^{2}$ T. Siewierski, Jak nie uprawiać historii historiografii: uwagi na marginesie artykułu Michała Kozłowskiego, PHW 2020, nr 1 (271), s. 241-250.

${ }^{3}$ M. Kozłowski, Historycy wojskowości - uczniowie Stanisława Herbsta, PHW 2019, nr 4 (270), s. 108-155.

${ }^{4}$ Idem, W odpowiedzi..., s. 217 
Spora część artykułu dotyczy wypromowanych przez Herbsta doktorów w ogóle. Autor sili się na zestawienia i podziały. Ewidentnie aspiruje do przedstawienia pełnej perspektywy. Nie wykluczam, że na Politechnice Warszawskiej żadnych uczniów Herbst nie pozostawił, ale należało to sprawdzić.

Nic nie usprawiedliwia rezygnacji z kwerendy w Archiwum Uniwersytetu Warszawskiego. W przypadku tak postawionego tematu to bezsprzecznie najważniejszy adres.

„Nie jest prawdą, jakoby moja kwerenda ograniczyła się tylko do zespołu dawnej Wojskowej Akademii Politycznej. Autor sam sobie zaprzecza, pisząc dalej, że zaniechałem tam kwerendy. W jaki sposób może ocenić, czy przeprowadziłem tam kwerendę, czy nie?"5

Rozumiem, że Autorowi chodzi o Centralne Archiwum Wojskowe Wojskowego Biura Historycznego (CAW-WBH). Jeżeli tak, to nie kwestionowałem, że Kozłowski poszukiwał tam źródeł: wszak w jego tekście roi się od sygnatur do licznych akt tej proweniencji (czy je czytał, to inna sprawa). Sformułowałem uwagę, że poszukiwania archiwalne w odniesieniu do uczniów Herbsta prowadził niemal wyłącznie w kręgu absolwentów Wojskowej Akademii Politycznej, a zespół WAP znajduję się obecnie w CAW-WBH.

\section{III}

„Nie odniosłem wrażenia, że Tomasz Siewierski jest znawcą tego archiwum i bywa w nim często - co pozwalałoby mu się stawiać na pozycji znawcy i autorytetu"6.

Tu znów Centralne Archiwum Wojskowe pozostaje w domyśle. Każdy $\mathrm{z}$ nas ma prawo do swoich wrażeń. Mam jednak nadzieję, że Kozłowski nie ma dostępu do ewidencji użytkowników akt (i listy obecności, jeżeli taka istnieje) w czytelni CAW-WBH. Oświadczam jednak uroczyście, iż akta z CAW-WBH, na które się powołuję, oglądałem osobiście w tejże czytelni. Zamawiałem je przy użyciu tradycyjnych rewersów w formie papierowej bądź elektronicznej. Pisząc całkiem poważnie, taka uwaga ze strony pracownika WBH jest co najmniej niepokojąca.

\footnotetext{
${ }^{5}$ Ibidem s. 217-218.

${ }^{6}$ Ibidem, s. 218.
} 
IV

„Uwzględniłem także materiały z Instytutu Pamięci Narodowej, czego autor zupełnie nie zauważył"”.

Zauważyłem. „Uwzględniłem...” brzmi przeuroczo, chodzi bowiem o jedną zaledwie teczkę dot. Czesława Blocha.

V

„Nie mogę też zrozumieć reakcji na wykorzystanie listy doktoratów obronionych na Wydziale Historycznym UW. Wszedłem w jej posiadanie dzięki uprzejmości dr. Siewierskiego i skorzystałem z jego rady, by się oprzeć na niej w pracy naukowej nad tematem".

Pozostawiając na marginesie wątpliwą kwestię czy udostępniałem wspomnianą listę Kozłowskiemu (nie pamiętam), oświadczam, że nie mogłem mu radzić, by opierał się na niej w pracy naukowej nad tematem. Po pierwsze, o tym, że Autor pracował nad tym zagadnieniem, dowiedziałem się z publikacji tekstu będącego przedmiotem sporu. Po drugie, lista może być pomocna, natomiast wymaga weryfikacji. Po trzecie, nie czynię uwag Autorowi z powodu, że z niej skorzystał. Problem w tym, że czerpał z niej niemało, jednak ani razu w swoim przeszło 40-stronicowym tekście o niej nie wspominając. Nie chodzi o pójście na łatwiznę, lecz o jaskrawą nieuczciwość.

VI

„Autor zupełnie nie rozumie relacji mistrz - uczeń, zarzucając mi nieuwzględnienie kilku osób. Nie traktuje się takiej relacji tylko jako formalnego zrobienia pod czyimś kierunkiem magisterium lub doktoratu. Idąc tym tokiem rozumowania, Bogdan Borusewicz jest uczniem Ryszarda Bendera, a Donald Tusk z kolei Romana Wapińskiego. Mam pewne wątpliwości, czy promotor doktoratu Tomasza Siewierskiego, prof. Mirosław Filipowicz, uznałby się za ucznia Czesława Blocha - swojego z kolei promotora. Stąd też uwagi o Barszczu i Jaworskim są zupełnie nietrafione"8.

Wydawało mi się, wnioskując choćby z tytułu artykułu Kozłowskiego, że pisał on o uczniach, a nie o „szkole historycznej”. O tym, czy rozumiem relacje „mistrz - uczeń” i jakie jest ich znaczenie w kontekście istnienia szkół, pisałem w książce Marian Małowist i krąg jego uczniów ${ }^{9}$. Autor może tego

\footnotetext{
${ }^{7}$ Ibidem.

${ }^{8}$ Ibidem.

${ }^{9}$ T. Siewierski, Marian Małowist i krag jego uczniów. Z dziejów historii historiografii gospodarczej w Polsce, Warszawa 2016.
} 
nie wiedzieć, mimo iż zechciał ją pozytywnie zrecenzować ${ }^{10}$. Dokonując omówienia, zdołał doliczyć się aż pięciu rozdziałów - ja napisałem zaledwie cztery...

Każdy absolwent studiów historycznych miał jakiegoś promotora. Kozłowski wymienia dwóch polityków, co jest dziwacznym przykładem, jeżeli już chcemy rozprawiać o „szkołach historycznych” i środowiskach naukowych. Poza tą dwójką Autor zechciał też wskazać na mojego mistrza, Mirosława Filipowicza (promotora mojej pracy magisterskiej oraz dysertacji doktorskiej), który rzeczywiście pracę magisterską napisał na seminarium Czesława Blocha (promotorem doktoratu zaś była Hanna Dylągowa). Jeżeli była to subtelna sugestia, iż jestem naukowym wnukiem Czesława Blocha, to naturalnie - tak, przyznaję się. Ale w zamian za moją publiczną deklarację $\mathrm{w}$ tej sprawie oczekiwałbym podobnego wyznania ze strony Michała Kozłowskiego. Wnioskuję, że nie będzie problemem publikacja przez niego oświadczenia zawierającego tytul, nazwisko promotora, datę i miejsce obrony pracy magisterskiej. Ciekaw jestem, kto uczył go warsztatu.

Co do Edwarda Barszcza i Mieczysława Jaworskiego - formalnie byli uczniami Herbsta. Być może nawiązali jakąś relację z Herbstem, która wytyczyła ich dalsze wybory, czy też styl pisarstwa. Tego nie wiemy. Natomiast nie uważam, że ignorancja (wynikająca z niewiedzy) jest właściwym postępowaniem w tej sprawie.

\section{VII}

„Przyznaję, że popełniłem błąd w przypadku Chęcińskiego, który nie obronił rozprawy doktorskiej. Jednak nie jest prawdą, że nie cytuję pracy Ireneusza Pielesiaka, gdyż robię to kilkakrotnie w tekście (s. 138, przyp. 91; s. 145, przyp. 116)"11.

Błąd w tej kwestii popełnił Ireneusz Pielesiak. Kozłowski ten błąd z jego pracy powielił. Zarzut mój polega na tym, iż w miejscu, gdzie ów błąd powiela, nie odsyła czytelnika do pracy Pielesiaka, lecz podaje sygnatury akt, z których wynika coś diametralnie innego.

\section{VIII}

Do ostatniej sprawy odniosę się już bez cytowania artykułu Kozłowskiego. Autor całkowicie nie zrozumiał moich zarzutów dotyczących jego „not

\footnotetext{
${ }^{10}$ M. Kozłowski, rec. Tomasz Siewierski, Marian Małowist i krag jego uczniów. Z dziejów historii historiografii gospodarczej w Polsce, Warszawa 2016, „Studia Podlaskie” 2018, s. 211-215.

${ }^{11}$ M. Kozłowski, W odpowiedzi..., s. 218.
} 
biograficznych" na temat m.in. Andrzeja Janowskiego i Czesława Blocha. W obu tych przypadkach Autor wykazał się nie tylko całkowitą nieznajomością epoki, w której obaj historycy funkcjonowali, ale też postanowił przybliżyć ich osiągnięcia w sposób daleki od rzetelności. Janowskiemu odmówił drukowanego dorobku - mimo jego istnienia. Czesława Blocha przedstawił nie tyle jako historyka, lecz w świetle wybranych, niedoprecyzowanych faktów z jego biografii politycznej. Podobnie jak p. Kozłowskiemu, materiały dot. Blocha zachowane w IPN ${ }^{12}$, jak też cenna i rzetelna praca Macieja Sobieraja ${ }^{13}$ są mi znane. Nie podważam informacji zawartych w tekście Kozłowskiego na temat Blocha. Dostrzegam jednak, że są one przedstawione w sposób nieprecyzyjny i wybiórczy. W odpowiedzi niczym „asa z rękawa” Kozłowski wyciągnął informacje o działalności brata Czesława Blocha, pracownika technicznego Komitetu Centralnego Polskiej Zjednoczonej Partii Robotniczej. Tylko co to ma do rzeczy?

W podsumowaniu Michał Kozłowski pisze o metodzie „kleju i nożyczek”. Cóż, wskazałem w jego tekście sześć, w moim przekonaniu poważnych patologii. W odpowiedzi Autor w istocie nie odniósł się do żadnej. Ponadto, nad czym ubolewam, Kozłowski całkiem niesłusznie potraktował moją recenzję w sposób personalny. Zarzuca mi negatywny stosunek do jego osoby. W mojej narracji dostrzega jakieś nieokreślone emocje. Odnosiłem się jedynie do tekstu i nie miało dla mnie znaczenia, kto jest jego autorem. Szkoda, że w podobny sposób nie zechciał się do mych zarzutów odnieść Kozłowski. Uznał za właściwe dywagowanie na temat liczby moich wizyt w CAW-WBH, włączenia kwestii moich nauczycieli, przypisywanie mi udzielania rad odległych od wyznawanych i przestrzeganych przeze mnie zasad pracy naukowej. Zarówno swoim artykułem, jak i odpowiedzią na moją recenzję dowiódł braku kompetencji, które powinien posiadać historyk. Tą myślą kończę definitywnie ze swojej strony dyskusję na temat tekstu Kozłowskiego.

Tomasz Siewierski

(Instytut Historii Nauki PAN) orcid.org/0000-0002-0059-3462

\footnotetext{
${ }^{12}$ Archiwum Instytutu Pamięci Narodowej w Lublinie, Akta personalne żołnierza: Czesław Bloch, sygn. 289/464.

${ }^{13}$ M. Sobieraj, Między oporem a lojalnościa. Działania SB wobec KUL na przykładzie rozpracowania prof. Jerzego Kłoczowskiego, Lublin 2015.
} 